\title{
A Study on the Role of Expectations and Perceived Organizational Support practices in Repatriate Turnover
}

\author{
Neeraj Kataria \\ University of Petroleum \& Energy Studies, Dehradun \\ Dr. Shweta Sethi \\ Swami Rama Himalayan University, Dehradun \\ Dr. P. C. Bahuguna \\ University of Petroleum \& Energy Studies, Dehradun
}

\begin{abstract}
MNCs are increasingly sending expatriates to their foreign subsidiaries in order to acquire best resources, and to cater to unexplored markets. This requires the executives to develop their global competencies. Once the expatriate has developed skills, far enough to sustain in the overseas, it becomes a challenge to settle him/her back in the home country when the expatriate assignment is over. Research evidences show that, there is a high percentage of repatriate turnover i.e the repatriate leaving the parent organization, upon return from the foreign assignment, resulting in both direct and indirect losses to the parent company. The purpose of this paper is to look into the reasons for repatriation turnover. The proposed model links repatriate turnover intentions to key causing factors such as repatriate expectation upon return and repatriate perception of organizational support practices. Data was gathered from 115 repatriates working in the major oil and gas industry, which included both government and private sector companies. The results of the study conclusively established that unmet expectations of expatriate were a significant cause for turnover intention of repatriate, while ineffective repatriation practices of company was not.
\end{abstract}

Keywords Expatriation, Repatriation, Turnover Intention, Repatriate expectation, Repatriation practices.

The oil and gas industry is one of the world's largest commercial sectors in terms of revenue, employing millions of people worldwide and contributing to global GDP. The major crude oil production countries are concentrated in the Middle East Asia, the American Subcontinent, and the Asia Pacific Region, while the refining centers are in the United States, Western Europe, and Asia Pacific. This necessitates a largescale logistics and supply chain network, involving the transportation of goods, materials, technologies, and people across international boundaries, transforming the oil and gas industry into a truly gigantic international industry requiring massive manpower flows. The vast and truly global nature of the oil and gas industry necessitates the flow of human talent across international boundary lines, frequently requiring short-term, medium-term, and long-term deputation of people in foreign, and sometimes remote, locations. As a result, expatriate management, which includes relocation to a foreign land and repatriation - rehabilitation back home after people return - is critical to the smooth and sustainable operations in the Oil \& Gas sector.

When it comes to sending expatriates to an overseas assignment, an MNC has a number of advantages. Expat workers are used for a variety of reasons, one of which is to improve their global experience and organizational learning. Expatriates improve their tangible skills during their foreign assignment, which adds value to the home country business (Lee, 2005). Expatriation is essential for businesses to build global competencies that are in line with their overall strategic human resource strategy. According to Evans, P. et al. (2002), the expatriation process has four phases: recruitment and selection, training and development, on assignment, and repatriation. An international assignment starts when an expatriate is deployed in a company's foreign subsidiary and ends when the expatriate returns home to the parent company as a repatriate at the end of the assignment (Bossard\& Peterson, 2005; Kraimer, Shaffer, Harrison, \& Ren, H. et.al.,2012; Suutari \& Brewster, 2003; Vidal, Valle, \& Aragón, 2007) 
The term "repatriation" refers to returning to one's home country after completing a foreign assignment (Dowling \& Shuler, 1990). In a global economy, repatriates are seen as tools for knowledge transfer and organizational learning, which are the foundations of organizational competitiveness (Burmeister \& Deller 2016, Lazarova \& Cerdin 2007; Vidal, Valle \& Aragon 2016). There is substantial research on the expatriation process of foreign assignments that has been published till date. The literature on repatriation process and practices is also scattered and incomplete. Perhaps this prejudice in the literature is due to the fact that returning home after a foreign assignment is mostly regarded as a nonproblematic and minor concern compared to going abroad (expatriation) (Black, 1992; Linehan \& Scullion, 2002).

However, evidence suggests otherwise. According to many studies, repatriates' turnover rate can be as high as 51\% after just two years of completion of expatriate assignment (Brookfield, 2015). Foreign assignments cost three to five times as much as the assignee's annual salary in his or her home country.

Failure to repatriate employees can be costly to organizations not only in terms of direct costs such as lost investment in repatriates (e.g., an average of USD \$1 million is spent on each international assignment (Kulkarni, Lengnick-Hall, \& Valk, 2010; Lazarova \& Caligiuri, 2001), but also in terms of indirect costs such as loss of skills, knowledge, and networks acquired and developed while placed abroad (Bolino, 2007; Cho, Hutchings, \& Marchant, 2013; Kraimer et al., 2012). Failures to repatriate also pose competitive risks because most repatriates often take positions in competing firms after their return (Kraimer et al., 2012). The anticipated benefits of expatriation will not be realized right away, as the repatriation process also involves some difficulties in readjusting to life in one's home country after a foreign experience.

Positive and statistically relevant relationships have been identified in hundreds of studies investigating leaving intentions and actual leaving activity (Schwepker 2001). In other words, the decision to quit a job precedes the actual departure. Turnover intention is commonly used as a measure of turnover in the workplace. A large number of previous studies have shown that turnover intention is often observed after repatriation. According to a report conducted by Baruch, Steele, \& Quantrill, 2002; Stroh et al., 1998, repatriate turnover rates ranged from $20 \%$ to $50 \%$. In their research, Suutari and Brewster (2003) found that 60 percent of repatriates seriously considered leaving after returning to their parent organizations. Previous research has found that the intention to remain or leave the company is reliably and strongly linked to voluntary turnover, and that the intent to stay or leave is the best indicator of actual turnover (Hendrix et al., 1999; Mowday et al., 1982).

Since measuring actual repatriate retention or turnover is difficult for two reasons, one, it's difficult to locate an employee after he/she has left the parent organization, and two, the employee may not relate his/ her expatriation assignment as a reason of turnover. Therefore, the current study used turnover intention as a substitute for actual turnover. Several researchers have discovered a variety of reasons for repatriate turnover intention, ranging from job dissatisfaction, unmet job expectations, perceived alternative employment, and a lack of effective organizational support practices for repatriation 
In the present study one of the construct taken is unmet expectations of an expatriate. An international assignment has certain expectations for both the entity and the organization. As a result of an international assignment, the organization views achievement of organizational tasks or key organizational objectives, value of the knowledge and skills expatriates obtain during expatriation and how these are transferred upon return, and repatriate retention as a few important expectations. Individuals, however, appear to be influenced by both push and pull factors when deciding whether or not to accept an expatriation (Suutari 2003; Haines, Saba and Choquette 2008). The positive motivations associated with the benefits of a foreign experience, such as learning and growth opportunities, are referred to as pull factors. Less favorable reasons, such as a lack of a suitable role in the home business, are referred to as "push factors." In their research, Suutari and Brewster (2003) discovered that the most common reason for expatriates to accept a foreign assignment is the hope that the assignment will improve their career prospects. Lower internal career growth prospects (in comparison to external opportunities) can be a predictor of employee turnover intentions (Stahl, Chua, Caligiuri, Cerdin, \& Taniguchi,2009). Job satisfaction factors such as work characteristics, remuneration, working environment, working relationship, working conditions, and job prospects. Job characteristics were identified as one of the key factors that were negatively linked to turnover intention in this research.

Another construct taken in the study is organizational repatriation practices. Although most companies have well-defined policies and procedures for hiring and sending expatriates overseas, few have policies in place for returning workers. Organizations do not see the need to pay attention to the repatriation aspect since expatriates are going home. As evident from the various research findings, most organizations pay close attention to the need for cross-cultural training and help for expatriates and make the appropriate arrangements, but such arrangements for repatriates are seldom considered. The organization's repatriation activities may have an effect on the repatriate's adjustment after returning from an international assignment. According to studies, repatriates have a high rate of attrition within the first year of their return due to disappointment with the repatriation method. Having an ongoing communication (Lazarova and Caligiuri 2001), a mentor in the domestic company during the abroad assignment (Swaak, 1997; Vermond, 2001), offering training to workers prior to their return (Jassawella, Connolly, and Slojkowski, 2004), and career management of repatriates have all been found to aid repatriates' adjustment. The satisfaction of repatriates with the repatriation procedure was also verified by Vidal et al. (2008) in their study of 124 Spanish repatriates as a factor in reducing repatriate turnover intentions.

\section{Theoretical Background and Hypothesis Development}

Repatriation performance is generally characterized in terms of the accomplishment of organizational activities or key organizational goals related to the repatriation process (e.g. Cerdin \& Le Pargneux, 2009; Yan et al., 2002). International assignees are exposed to new insights, innovations, business practices, key local suppliers and customers, global cultures, and national markets while on assignment abroad, allowing them to acquire new and useful international management skills and personal properties (Lazarova \& Tarique, 2005). Repatriates are critical to an organization's success because they serve as bridges between operations in the home and host countries (Lazarova \& Cerdin, 2007; Oddou et al., 2009). When the assignees return, these newly acquired skills and knowledge have the potential 
to contribute to the creation of new know- how within their firms, which can lead to organizational competitive advantages (Lazarova \& Cerdin, 2007; Oddou et al., 2009). Thus retention of repatriates is a critical outcome for businesses. However earlier studies have identified repatriate attrition as a major organizational problem in the repatriation process. Organizations, with a few exceptions and for unknown purposes, appear to ignore the importance of facilitating a smooth transfer from foreign assignment to reentry, to the detriment of both individuals and businesses.

Repatriates often return to their home country with aspirations that are incompatible with the realities of the world to which they are returning, resulting in disappointment with their new situation. They feel undervalued when they return to a job where they have less authority and are unable to put their newly learned skills to use after successfully completing an overseas assignment with substantial management responsibilities and autonomy. Literature suggests that unmet expectations of repatriates related to career advancement and promotional opportunities, work assignments, support from managers and peers after repatriation acts as the major contributory factors influencing the turnover intention of employees (Black et al., 1992). Another reason contributing to turnover intent of repatriates was found to be the organisational repatriation practices (Bossard \& Peterson, 2005). According to Lazarova and Caligiuri's (2001), the organisational practices like repatriates pre-departure briefings, career planning, clarity and agreement on the position to be offered upon repatriation, repatriation training programs, lifestyle assistance, and counseling were found to be associated with successful repatriation programs and showed significant impact on lowering the turnover intention of repatriates.

According to the preceding discussion, ineffective repatriate management can result in increased repatriate turnover. Although there is profound literature on the causes of repatriate turnover across industries, there is a scarcity of literature on the robustness of the causal factors of repatriate turnover in India's oil and gas industry. As a result, the oil and gas industry was chosen to investigate the impact of unmet repatriate expectations and organizational repatriation practices on repatriate turnover intention. Figure 1 shows a symmetrical representation of the same.

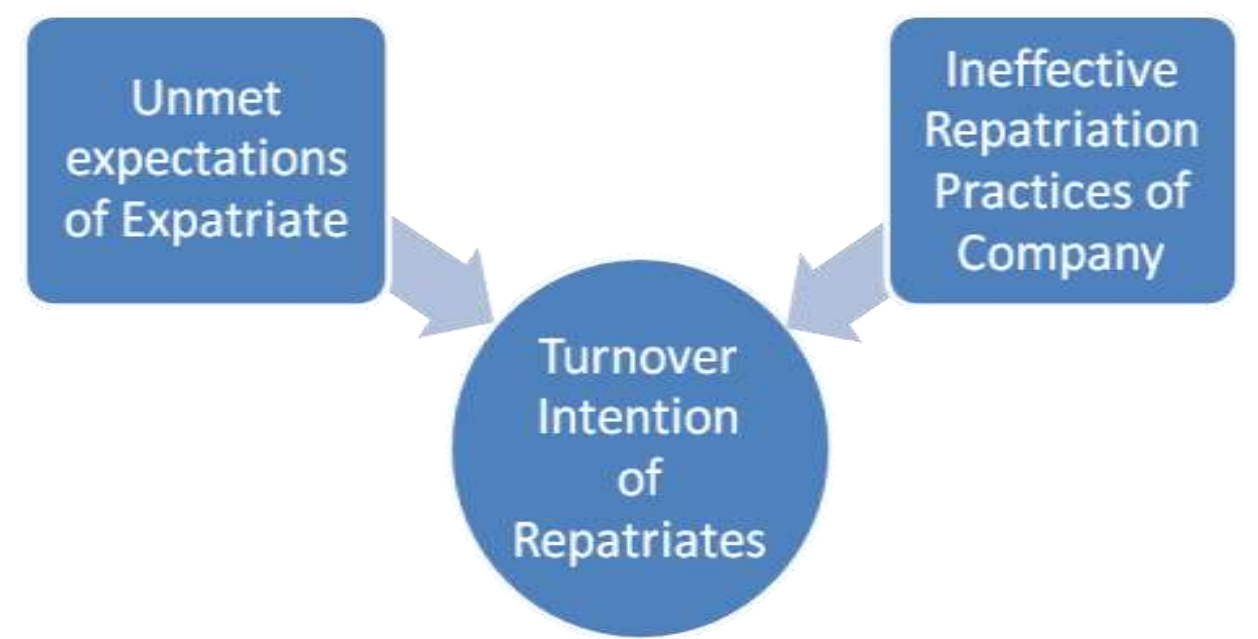

Figure 1. Theoretical Framework

Source: The author. 
Unfulfilled expatriate expectations and ineffective repatriation practices of a company are considered as independent variables for this purpose. To accomplish this goal, the relationships between repatriate turnover intention and two independent variables (unfulfilled expatriate expectations and ineffective repatriation practices of a company) were examined while observing the overall effect of these variables on repatriate turnover intention. As a result, the following is proposed:

H1: Unfulfilled expectations of an expatriate leads to turnover intention among the repatriates.

\section{H2: Ineffective repatriation practices of the company leads to turnover intention among the repatriates}

The study variables: unfulfilled expectations of an expatriate and ineffective repatriation practices of the company were measured on a five-point likert-type scale ranging from strongly disagree to strongly agree (where 1 = strongly disagree, 5 = strongly agree).

The items for them were developed after in-depth understanding of past literature on the subject matter as well as repeated consultation with resource persons such as practitioners, working as HR professionals in Oil \& Gas sector, working in consulting firms such as KPMG, Deloitte etc. and academia involved in HRM and International HRM. The items were finally reversed coded to represent inadequacy. The turnover intention among the repatriates were again captured on a five-point scale ranging from not at all important to very important (where $1=$ Not at all important and $5=$ Very important).

\section{Data Collection}

Quota sampling was used to collect the data. The population for the study consisted of Repatriates in major oil and gas industry comprising of Government sector and private sector companies. The number of questionnaires used for the study was 115 . The demographic distribution of the sample is represented in Table 1.

Table-1 Frequency Table for Demographic Variables Taken up in the Study

\begin{tabular}{|l|c|c|}
\hline Demographic variable & Frequency & Percent \\
\hline Gender & 79 & 69 \\
Male & 36 & 31 \\
Female & 115 & 100 \\
Total & & \\
\hline Marital status & 63 & 55 \\
Single & 3 & 3 \\
Married \& Separated & 49 & 42 \\
Married & 115 & 100 \\
Total & & \\
\hline Educational Qualification & 19 & 17 \\
Under Graduate & 32 & 28 \\
Graduate & 15 & 13 \\
Graduate Diploma & 49 & 42 \\
Postgraduate & 115 & 100 \\
Total & & \\
\hline Age & 56 & 49 \\
25-40 & 45 & 39 \\
$41-56$ & 14 & 12 \\
57-72 & 115 & 100 \\
Total & & 62 \\
\hline No of Children & 71 & 15 \\
Zero & 17 & 20 \\
One & 23 & 03 \\
Two & 4 & 100 \\
More & 115 & 6 \\
Total & 7 & \\
\hline Designation & & \\
Executive Director & & \\
\hline
\end{tabular}




\begin{tabular}{|l|c|c|}
\hline Vice President & 9 & 17 \\
General Manager & 19 & 8 \\
Manager & 53 & 46 \\
Sr. Executive/Executive & 27 & 23 \\
Total & 115 & 100 \\
\hline & & \\
Duration of Assignment in Yrs. & 14 & 12 \\
6 Months - 1 Year & 23 & 20 \\
1 Year - 2 years & 41 & 36 \\
2 Years - 3 years & 29 & 25 \\
3 Years - 4 years & 8 & 7 \\
4 years - 5 years & 115 & 100 \\
Total & & \\
\end{tabular}

\section{Reliability and Validity}

The questionnaire was pilot tested with a small sample of 40 respondents to check the reliability and validity of scales developed by the authors. The content validity of the instruments was assumed as items were developed through a rigorous process of systematic literature review and then subjected to consultation with subject matter experts. Data reliability was checked through construct reliability and Cronbach's alpha. The Cronbach's Alpha coefficients were more than 0.85 for all study measures, indicating sufficient consistency.

\section{Analysis of Data}

A linear multiple regression model was performed for testing the Proposed Theoretical Model. The Unfulfilled expectations of an expatriate and Ineffective repatriation practices of the company as independent variables were allowed to explain variance into the dependent variable i.e. turnover intention. The results of the analysis are presented below in the following tables.

Table 2: Model Summary

\begin{tabular}{|l|l|l|l|}
\hline$R$ & R Square & Adjusted R Square & Std. Error of the Estimate \\
\hline $\mathbf{0 . 5 4 1 7 4 2}$ & $\mathbf{0 . 2 9 3 4 8}$ & 0.2316 & 0.213 \\
\hline
\end{tabular}

As can be seen, from the ANOVA Table 3, the overall regression model is significant even at $1 \%$ level of significance $(F=66.2018 ; p=.0001<.01)$. Out of the total sum of squares (SSTotal $=997.014)$, the sum of squares explained by the linear regression line (SSregression= 540.124) which is a good proportion and reasonably higher than the residual sum of squares $($ SSresidual $=456.89)$. This explicitly indicates that the regression model is quite robust and fitted to the data.

Now, looking at the $\mathrm{R}$ square value from Table $2(\mathrm{R}$ square $=0.29348)$, around 30 percent of the variance is explained by the independent variables together (Unfulfilled expectation and Ineffective repatriation practices) into the dependent variable i.e., turnover intention. Therefore, the null hypothesis is straightaway rejected even at $1 \%$ level of significance. However, it will now be important to see whether both of the beta coefficients have been significant in explaining turnover intentions of repatriates.

Table 3: ANOVA

\begin{tabular}{|l|c|c|c|c|c|}
\hline$\underline{\text { Source of variation }}$ & $\underline{\text { Sum of Squares }}$ & $\underline{\text { Df }}$ & $\underline{\text { Mean Square }}$ & $\underline{F}$ & $\underline{\text { Sig. }}$ \\
\hline$\underline{\text { Regression }}$ & $\underline{540.124}$ & $\underline{2}$ & $\underline{270.062}$ & $\underline{66.2018}$ & $\underline{0.0001}$ \\
\hline$\underline{\text { Residual }}$ & $\underline{456.89}$ & $\underline{112}$ & $\underline{4.07938}$ & - & - \\
\hline$\underline{\text { Total }}$ & $\underline{997.014}$ & $\underline{114}$ & - & - & - \\
\hline
\end{tabular}


From the coefficient Table 4, the beta coefficient for Unfulfilled expectation is found to be statistically significant even at one percent level of significance $(b=0.977 ; t=5.531 ; p=.0002<.01)$ indicating that Unfulfilled expectations of repatriates is significant factor leading turnover intentions. However, Ineffective repatriation practices turned out to be insignificant $(b=0.1072 ; t=1.085 ; p=.0 .114>.05)$ in explaining turnover intentions.

Table Error! No text of specified style in document.: Coefficients

\begin{tabular}{|l|l|l|l|l|l|}
\hline$\underline{\text { Source of variation }}$ & $\underline{\text { Unstandardized Coefficients }}$ & $\underline{\text { Stand. Beta }}$ & $\underline{\mathrm{T}}$ & $\underline{\text { Sig }}$ \\
\hline & $\underline{\mathrm{B}}$ & $\underline{\text { Std. Error }}$ & $\underline{\text { Beta }}$ & & \\
\hline$\underline{\text { (Constant) }}$ & $\underline{.811}$ & $\underline{0.262}$ & & $\underline{4.0132}$ & $\underline{0.000}$ \\
\hline$\underline{\text { Unfulfilled expectation }}$ & $\underline{0.977}$ & $\underline{0.21}$ & $\underline{0.5417}$ & $\underline{5.531}$ & $\underline{0.0002}$ \\
\hline$\underline{\text { Ineffective repatriation practices }}$ & $\underline{0.1072}$ & $\underline{0.075}$ & & $\underline{1.085}$ & $\underline{0.114}$ \\
\hline
\end{tabular}

** Dependent variable: Employee association

Hence, the null hypothesis- 1 is rejected at $1 \%$ but the test failed to reject the null hypothesis- 2 .

\section{Discussion and Conclusion}

The results of the study conclusively established unmet expectations of expatriate were a significant cause for turnover intention of repatriate, while ineffective repatriation practices of company was not. Thus the hypothesis- 1 is accepted at even $1 \%$ but the test failed to accept the hypothesis- 2 at $5 \%$.

Table 5: Summary of hypotheses testing of the proposed model

\begin{tabular}{|l|l|}
\hline Hypothesis and its Description & Results \\
\hline H1: Unfulfilled expectations of an expatriate leads to turnover intention among the repatriates. & Supported \\
\hline $\begin{array}{l}\text { H2: Ineffective repatriation practices of the company leads to turnover intention among the } \\
\text { repatriates }\end{array}$ & Not Supported \\
\hline
\end{tabular}

The Unfulfilled expectations of an expatriate and Ineffective repatriation practices of the company as independent variables were allowed to explain variance into the dependent variable i.e., turnover intention. The overall regression model was found to be statistically significant even at $1 \%$ level of significance $(\mathrm{F}=66.2018 ; \mathrm{p}=.0001<.01)$. Approximately, 30 percent of the variance was jointly explained by the independent variables (i.e., unfulfilled expectations and ineffective repatriation practices) into the dependent variable i.e., repatriate turnover intention.

In the present study, unfulfilled expectations of the repatriates were found to be a significant factor leading to repatriate turnover intention $(\mathrm{b}=0.977 ; \mathrm{t}=5.531 ; \mathrm{p}=.0002)$, thought ineffective repatriation practices turned out to be insignificant in explaining turnover intentions $(b=0.1072 ; t=1.085 ; \mathrm{p}=.114)$ at $5 \%$ level of significance.

This is an important finding to human resource managers as repatriate turnover continues to be a challenge for organizations. Organizations lose the skills and knowledge that repatriates gain through their foreign assignments when repatriated employees leave their jobs. With the substantial costs of training and salary for each employee sent abroad, repatriate turnover also represents a significant financial burden. Thus, the assumption that was made by the institution that expatriate managers will 
return home with international expertise that will benefit the organization (O'Sullivan, 2002), remains just an assumption and not the reality. In the present study majority of expatriates reported higher earnings and career growth as the most prominent reasons for accepting an international assignment. Though while capturing the data pertaining to repatriation consequences, it was found that the expectation of career advancement was not met as only a few repatriates reported that career progression was awarded to them on their return to the home country (India). This finding is particularly crucial since problems encountered upon return mostly arise from unmet expectations and the perceived gap between expectations and realities. The expectations of individuals can be either positive or negative and both may lead to different consequences when repatriates see realities (Hammer, Hart, and Rogan, 1998).

Thus, it is recommended that the right communication be made for forming accurate expectations else the MNC's may lose international exposure gained by expatriates once they return home country.

\section{Limitations and Future Research}

The current study, like any other, was hampered by specific constraints, which may have resulted in limitations. Future researchers may take the torch of knowledge forward and expand on the knowledge base established in this work.

The phenomenon of "turnover intention of repatriation" is used as a proxy for true turnover in this study, which may result in a skewed conclusion. This is because the study focused on repatriates who were still employed by the parent company, which is not the greatest group of people to analyze repatriation turnover. The repatriates who have left the parent company after returning from overseas assignments could be studied by future scholars. When such personnel leave the company, it will be tough to track them down when they return home.

\section{Conflict Of Interest}

This study is undertaken solely for academic interests. In the study design, data collection method, and data analysis and interpretation, no organization or sponsor plays a role. The findings are completely based on the information gathered.

\section{References}

Baruch, Y., Steele, D. J., \& Quantrill, G. A. (2002). Management of expatriation and repatriation for novice global player. International Journal of Manpower, 23, 659-671.

Black, J. S. (1992). Coming home: The relationship of expatriate expectations with repatriation adjustment and job performance. Human Relations, 45, 177-192.

Bolino, M. C. (2007). Expatriate assignments and intra-organizational career success: Implications for individuals and organizations. Journal of International Business Studies, 38, 819-835.

Bossard, A. B., \& Peterson, R. B. (2005). The repatriate experience as seen by American expatriates. Journal of World Business, 40, 9-28.

Brookfield (2015). Global relocation trends: 2015 survey report. Chicago, IL: Brookfield Global Relocation Services .

Burmeister, A., \& Deller, J. (2016). A practical perspective on repatriate knowledge transfer: The influence of organizational support practices. Journal of Global Mobility: The Home of Expatriate Management Research, 4, 68-87. 
Cerdin, J.-L., \& Le Pargneux, M. (2009). Career and international assignment fit: Toward an integrative model of success. Human Resource Management, 48, 5-25.

Cho, T., Hutchings, K., \& Marchant, T. (2013). Key factors influencing Korean expatriates' and spouses' perceptions of expatriation and repatriation. The International Journal of Human Resource Management, 24, 1051-1075.

Dowling, P.J., \& Shuler, R.S. (1990). International dimensions of human resource management. Boston: PWA/Kent.

Evans, P.; Pucik, V.; Barsoux, J. (2002). The Global Challenge: Frameworks for International Human Resource Management. New York: McGraw-Hill.

Haines V.Y; Saba, T \& Choquette, E. (2008). Intrinsic motivation for an international assignment, International journal of manpower 29(5), 443-461.

Hammer, M. R., Hart, W., \& Rogan, R. (1998). Can you go home again? An analysis of the repatriation of corporate managers and spouses. Management International Review, 38, 67-86.

Hendrix, W.H., Robbins, T., \& Summers, T.P. (1999). Effects of procedural and distributive justice on factors predictive of turnover. Journal of Social Behavior and Personality, 13, 4, 611-632.

Jasswella, A., Connolly, T., \& Slojkowski, L. (2004). Issues of effective repatriation: A model and managerial implications. SAM Advanced Managerial Journal, 69, 2, 38-46.

Kraimer, M. L., Shaffer, M. A., Harrison, D. A., \& Ren, H. (2012). No place like home? An identity strain perspective on repatriate turnover. Academy of Management Journal, 55, 399-420.

Kraimer, M. L., Shaffer, M. A., Harrison, D. A., \& Ren, H. (2012). No place like home? An identity strain perspective on repatriate turnover. Academy of Management Journal, 55, 399-420.

Kulkarni, M., Lengnick-Hall, M. L., \& Valk, R. (2010). Employee perceptions of repatriation in an emerging economy: The Indian experience. Human Resource Management, 49, 531-548.

Lazarova, M., \& Cerdin, J. L. (2007). Revisiting repatriation concerns: Organizational support versus career and contextual influences. Journal of International Business Studies, 38, 404- 429.

Lazarova, M., \& Tarique, I. (2005). Knowledge transfer upon repatriation. Journal of World Business, 40, 361-373.

Lazarova, M., \& Caligiuri, P. (2001). Retaining repatriates: The role of organizational support practices. Journal of World Business, 36, 389-401.

Lazarova, M., \& Caligiuri, P. (2001). Retaining repatriates: The role of organizational support practices. Journal of World Business, 36, 389-401. 
Lazarova, M., \& Cerdin, J. L. (2007). Revisiting repatriation concerns: Organizational support versus career and contextual influences. Journal of International Business Studies, 38, 404-429.

Lee, H.W. (2005). The factors influencing Expatriates. Journal of American Academy of Business, 6(2), 273-279, Cambridge, Hollywood

Linehan, M., \& Scullion, H. (2002a). Repatriation of European female corporate executives: An empirical study. The International Journal of Human Resource Management, 13, 254-267.

Mowday, R.T., Porter, L.W., \& Steers, R.M. (1982). Employee-organization linkage: The psychology of commitment, absenteeism, and turnover. New York: Academic Press.

O'Sullivan, S. L. (2002). The protean approach to managing repatriation transitions. International Journal of Manpower, 23, 597-616.

Oddou, G., Osland, J. S., \& Blakeney, R. N. (2009). Repatriating knowledge: Variables influencing the "transfer" process. Journal of International Business Studies, 40, 181-199.

Ren, H., Bolino, M. C., Shaffer, M. A., \& Kraimer, M. L. (2013). The influence of job demands and resources on repatriate career satisfaction: A relative deprivation perspective. Journal of World Business, 48, 149-159.

Schwepker, C. H. (2001). 'Ethical climate"s relationship to job satisfaction, organizational commitment, and turnover intention in the Salesforce', Journal of Business Research, 54(1), pp.39-52

Stahl, G. K., Chua, C. H., Caligiuri, P., Cerdin, J. L., \& Taniguchi, M. (2009). Predictors of turnover intentions in learning-driven and demand-driven international assignments: The role of repatriation concerns, satisfaction with company support, and perceived career advancement opportunities. Human Resource Management, 48, 89-109.

Stroh, L. K., Gregersen, H. B., \& Black, J. S. (1998). Closing the gap: Expectations versus reality among repatriates. Journal of World Business, 33, 111-124.

Suutari, V., \& Brewster, C. (2003). Repatriation: Empirical evidence from a longitudinal study of careers and expectations among Finnish expatriates. International Journal of Human Resource Management, 14, 1132-1151.

Swaak, R. (1997). Repatriation: A weak link in global HR. HR Focus, 74(4), 29-31.

Vermond, K. (2001). Expatriates come home. Management, 75(7), 30-34.

Vidal, E.S., Valle, R.S., \& Aragon, I.B. (2008). International workers' satisfaction with the repatriation process. The International Journal of Human Resource Management, 19, 9, 1683-1702.

Vidal, M. E. S., Valle, R. S., \& Aragón, M. I. B. (2008). International workers' satisfaction with the repatriation process. The International Journal of Human Resource Management, 19, 1683-1702. 
Vidal, M. E. S., Valle, R. S., \& Aragón. (2016). Repatriates and reverse knowledge transfer in MNCs. International Journal of Human Resource Management.

Yan, A., Zhu, G., \& Hall, D. T. (2002). International assignments for career building. Academy of Management Review, 27, 373-383. 